\title{
Sejmik wielkopolski. Przeszłość i teraźniejszość, pod red. Andrzeja Kamieńskiego, Wydawnictwo Naukowe Uniwersytetu Szczecińskiego, Szczecin - Jarocin 2008, 183 strony.
}

Prezentowana pozycja stanowi pokłosie jednodniowej sesji naukowej w Jarocinie, która została zorganizowana przez Zamiejscowy Wydział Administracji Uniwersytetu Szczecińskiego w Jarocinie, Wielkopolską Wyższą Szkołę Humanistyczno-Ekonomiczną w Jarocinie, Sejmik Województwa Wielkopolskiego oraz poznański oddział Polskiego Towarzystwa Historycznego. Znalazło się w niej 12 tekstów będących dziełem grupy historyków, prawników oraz samorządowców, traktujących o samorządzie wielkopolskim w różnym ujęciu, zarówno czasowym, jak i problemowym.

Zgodnie z tytułem tomiku, zagadnieniom historycznym sejmiku wielkopolskiego poświęcono pierwszą część książki. Omówiono w niej średniowieczne początki wielkopolskich zgromadzeń ziemskich, wybrane kwestie z zakresu funkcjonowania sejmiku województw poznańskiego i kaliskiego w okresie I Rzeczypospolitej, funkcjonowanie XIX-wiecznego Sejmu Prowincjonalnego Wielkiego Księstwa Poznańskiego oraz samorząd wojewódzki działający w Wielkopolsce w okresie międzywojennym.

Druga część publikacji zawiera $\mathrm{z}$ kolei aktualne sprawy związane z funkcjonowaniem samorządu województwa wielkopolskiego, a więc kwestie jego pozycji prawnej, problematykę podmiotowości regionalnej wspólnoty samorządowej, zadania jakie na nim ciążą, uwzględniając przy tym szczegółowe zagadnienia, jak samorządowa polityka finansowa i kulturalna.

Historyka prawa siłą rzeczy interesują problemy historyczne, stąd pozwolę sobie skupić się w recenzowanej pozycji na części pierwszej, nie umniejszając przy tym znaczenia części drugiej i mając na względzie fakt, że zorganizowana sesja naukowa oraz publikacja stawiały sobie za cel przybliżenie współczesnym Wielkopolanom bogatej tradycji samorządowej własnego regionu.

A. Lityński pisał przed laty o instytucji sejmiku szlacheckiego, że stanowił on praw i swobód domiclilium ${ }^{1}$. Sejmik I Rzeczypospolitej był dobrowolnym zgromadzeniem członków stanu uprzywilejowanego, którym była szlachta danej ziemi, województwa czy prowincji i odgrywał dwojaką rolę. Stanowił podstawową instytucję szlacheckiego samorządu lokalnego i był zarazem głównym sposobem uczestnictwa szlachty w życiu politycznym państwa. Wśród historyków, na co zwrócił uwagę w swoim tekście J. Wijaczka (Sejmiki wielkopolskie a Żydzi w czasach wczesnonowożytnych), brak jest zgodności co do genezy sejmików wielkopolskich, a więc sejmików: województwa brzesko-kujawskiego i inowrocławskiego, ziemi dobrzyńskiej, województwa łęczyckiego, województw

1 A. Lityński, Sejmiki w dawnej Rzeczpospolitej. Problemy badawcze, „Czasopismo Prawno-Historyczne" 1996, z. 1-2, s. 60. 
poznańskiego i kaliskiego, województwa sieradzkiego, ziemi wieluńskiej, województwa gnieźnieńskiego (wydzielonego z województwa kaliskiego). Przyjąć należy jednak za J. Doboszem, który w swoim artykule poszukiwał korzeni instytucji sejmiku w Wielkopolsce (Od wieców i zjazdów do sejmików), twierdzenie, że uformowanie się szlacheckiego samorządu lokalnego (ziemskiego) nastąpiło w wyniku wzrostu znaczenia szlachty i ostatecznego zdominowania przez nią innych warstw: chłopstwa, mieszczan, duchowieństwa. Przedstawiając funkcjonowanie instytucji sejmiku na przykładzie sejmiku województw poznańskiego i kaliskiego, zajmującego nie tylko w Wielkopolsce, ale także w Koronie czołowe miejsce wśród sejmików, M. Zwierzykowski (Funkcjonowanie samorzadu sejmikowego województw poznańskiego kaliskiego od XVI do XVIII wieku) doskonale scharakteryzował strukturę i rodzaje sejmików, ich kompetencje, a także cały proces sejmikowania. Na wysoką ocenę zasługuje także zobrazowanie całokształtu instytucji związanych z sejmikiem i uwypuklenie obszernej sfery kompetencji sejmiku, którą stanowiły szeroko rozumiane sprawy samorządowe. Ta sfera szlacheckiego samorządu lokalnego w dotychczasowej historiografii była bowiem zwykle marginalizowana na rzecz przedstawiania kompetencji politycznych sejmiku. W tekście M. Zwierzykowskiego zabrakło mi poruszenia tylko jednej kwestii, a mianowicie zwrócenia uwagi na zagadnienie czynników wpływających na uchwały sejmikowe - dworu królewskiego, przedstawicieli innych sejmików, a w szczególności osób związanych z obszarem oddziaływania sejmiku, przykładowo dla sejmiku średzkiego senatorów z województw poznańskiego i kaliskiego. Lukę tę w pewien sposób uzupełniają kolejne teksty. A. Kamieński (Problem ochrony obrad zgromadzeń ziemskich $w$ Polsce XVI-XVIII w. <Na przykładzie sejmiku województwa poznańskiego i kaliskiego $w$ Środzie $>$ ), pisząc o problemie ochrony obrad zgromadzeń ziemskich w Polsce XVI-XVIII wieku, wskazywał, że „opanowane przez stronnictwa magnackie sejmiki stały się szybko areną walki politycznej oraz wyrazem najzamożniejszej grupy społeczeństwa szlacheckiego, która wpływała na kształt podejmowanych uchwał, a w razie zagrożenia własnych interesów tamowała czynności doprowadzając do zerwania obrad”. Z kolei J. Wijaczka badając relacje sejmiki wielkopolskie - Żydzi zauważał, iż gminy żydowskie były bardzo zainteresowane przebiegiem sejmików szlacheckich i dążyły do tego, by w ich trakcie nie zapadały postanowienia nieprzychylne Żydom.

Sejmiki były instytucjami, które od początku swego istnienia ewaluowały, a omawiana publikacja potwierdza tę tezę. Potwierdza również fakt, że poziom naszej wiedzy na temat sejmików wielkopolskich jest wciąż niewystarczający. Brakuje prac, na co słusznie zwrócił uwagę M. Zwierzykowski, o sejmikach doby stanisławowskiej, a także prac problemowych, dotykających kwestii funkcjonowania szlacheckiego samorządu.

Również okres zaborów jest słabo przebadany. C. Myschor w swoim artykule (Sejm Prowincjonalny Wielkiego Księstwa Poznańskiego/Prowincji Poznańskiej 1827-1918), w którym scharakteryzował XIX-wieczny Sejm Prowincjonalny Wielkiego Księstwa Poznańskiego/Prowincji Poznańskiej, dokonał w tym zakresie pracy pionierskiej. Przedstawienie podstaw prawnych, a także ukazanie wypracowanego w tym czasie sposobu działania organów samorządowych stanowią ważny wstęp do zrozumienia funkcjonowania samorządu wojewódzkiego w Wielkopolsce w II Rzeczypospolitej. 
G. Kucharczyk (Samorząd wojewódzki w Wielkopolsce w prawodawstwie II Rzeczypospolitej) w swoim krótkim tekście, traktującym o samorządzie wojewódzkim w Wielkopolsce w okresie międzywojennym, odniósł się tylko do ram prawnych i organizacyjnych funkcjonowania sejmiku wojewódzkiego, postulując jednocześnie podjęcie szerszych badań nad działalnością samorządową w Wielkopolsce. Autor, opisując kształtowanie się ustroju samorządu wojewódzkiego w okresie II Rzeczypospolitej zauważył, że pełen samorząd wojewódzki istniał tylko w województwach poznańskim i pomorskim, co było spuścizną po zaborze pruskim oraz pozostawiony został tam mimo wprowadzenia w 1933 r. jednolitej organizacji samorządu terytorialnego, o czym nie przeczytamy w niektórych podręcznikach akademickich.

Przedstawione w prezentowanym tomiku dzieje samorządu w Wielkopolsce pokazują, że „funkcjonujący obecnie sejmik samorządowy kontynuuje dzieło zapoczątkowane przez mieszkańców Wielkopolski w głębokim średniowieczu” (A. Kamieński, Wstęp). Pokazują również fenomen, jakim była ciągłość wielkopolskiego samorządu terytorialnego w okresie zaborów i II Rzeczypospolitej. By obraz historyczny był jednak pełny, należało poświęcić trochę miejsca losom samorządu terytorialnego po drugiej wojnie światowej, co bynajmniej nie powinno zabrzmieć jak zarzut, gdyż cała praca niewątpliwie wzbogaca dotychczasową literaturę przedmiotu.

Diana Maksimiuk 